\title{
ANALISIS PUTUSAN PENGADILAN NIAGA TERKAIT AKIBAT HUKUM PERMOHONAN PKPU YANG DIAJUKAN OLEH PIHAK YANG TIDAK BERWENANG (STUDI KASUS PUTUSAN PENGADILAN NIAGA PADA PENGADILAN NEGERI JAKARTA PUSAT NOMOR 24/PDT.SUS-PKPU/2018/PN.NIAGA.JKT.PST)
}

\author{
Regina Nitami Kasdi \\ (Mahasiswa Program S1 Fakultas Hukum Universitas Tarumanagara) \\ (E-Mail: nitamiregina@yahoo.com)
}

\author{
Dr. F. X. Suyud Margono, S.H., M.Hum., FCIArb. \\ (Corresponding Author)
}

(Dosen Fakultas Hukum Universitas Tarumanagara. Meraih Sarjana Hukum pada Fakultas Hukum Universitas Atmajaya (1998), Magister Hukum Pada Fakultas Hukum Universitas Tarumanagara (2004), Doktor Ilmu Hukum (Dr.) pada Fakultas Hukum Universitas Parahyangan (2011)

(E-Mail: suyudm@fh.untar.ac.id)

\begin{abstract}
Indonesia is currently developing a rapidly growing economy so that various kinds of debt problems arise due to efforts to increase capital or develop a business. One effort that can be done to resolve this debt and credit problem is to submit a bankruptcy application or PKPU if simple requirements are met as specified in Law No. 37 of 2004. PKPU is an effort made by debtors and creditors with the intention to propose a peace plan which includes offering the payment of part or all of the debt to creditors regarding the settlement of debts between them. In Law No. 37 of 2004 is specifically regulated regarding the party authorized to submit PKPU applications, namely in Article 222 Paragraph (1) regulated that the Parties that can submit PKPU requests are Debtors or Creditors, so PKPU requests may not be submitted by outside parties as specified in the law. Therefore, the problem raised by the author is due to the legal submission of PKPU requests submitted by unauthorized parties in view of Law Number 37 of 2004 Concerning Bankruptcy and Delaying Obligations for Debt Payment. Even though the law has specifically regulated the parties who can submit PKPU requests, there are still PKPU requests submitted by unauthorized parties. The legal consequence of a PKPU petition filed by a party outside of what has been specified in the bankruptcy law and PKPU is that such a request must be rejected by a court judge examining the case.
\end{abstract}

Keywords: PKPU, Legal Standing, Corporate.

\section{PENDAHULUAN}

\section{A. Latar Belakang}

Zaman sekarang ini, perekonomian dan perdagangan di Indonesia berkembang sangat pesat yang kemudian mendorong timbulnya permasalahan-permasalahan utang piutang yang timbul akibat upaya untuk meningkatkan modal ataupun mengembangkan suatu usaha. 
Regina Nitami Kasdi \& F.X. Suyud Margono

ANALISIS PUTUSAN PENGADILAN NIAGA

Jurnal Hukum Adigamâ

TERKAIT AKIBAT HUKUM PERMOHONAN PKPU YANG

DIAJUKAN OLEH PIHAK YANG TIDAK

(STUDI KASUS PUTUSAN PENGADILAN NIAGA

PADA PENGADILAN NEGERI JAKARTA PUSAT

Volume 2 Nomor 2, Desember 2019

NOMOR 24/PDT.SUS-PKPU/2018/PN.NIAGA.JKT.PST)

E-ISSN : 2655-7347

Permasalahan ini dapat terjadi apabila pihak yang berutang tidak dapat melaksanakan kewajibannya untuk melunasi utang-utangnya terhadap pihak yang memegang piutang. Dalam hal ini pihak yang berpiutang (kreditor) akan melakukan berbagai upaya yang dapat dilakukan untuk memaksa pihak yang berutang (debitor) agar membayar utang-utangnya.

Upaya yang biasanya dilakukan oleh kreditor dalam hal kreditor melihat bahwa debitor sudah tidak memiliki kemampuan sama sekali untuk membayar utangnya adalah kreditor akan mengajukan permohonan kepailitan yang akan mengakibatkan disitanya harta (aset) debitor untuk melunasi utang tersebut. Namun apabila kreditor ini melihat bahwa masih kemungkinan bagi debitor unutk menyelesaikan pembayaran utang-utangnya maka kreditor dapat memohonkan duatu permohonan Penundaan Kewajiban Pembayaran Utang yang biasa disingkat dengan istilah PKPU.

Pengunduran Pembayaran atau Penundaan Pembayaran yang diatur di dalam Bab kedua peraturan kepailitan yang lama, mengatur tentang Pengunduran Pembayaran atau biasanya di sebut juga dengan Penundaan Pembayaran yang kemudian judulnya di ubah menjadi Penundaan Kewajiban Pembayaran Utang atau (PKPU) yang diatur dalam Bab kedua Perpu Nomor 1 Tahun 1998 yang selanjutnya ditetapkan menjadi undang-undang dengan Undang-Undang Nomor 4 Tahun 1998, dalam undang-undang ini perihal PKPU di mulai dari Pasal 212 s/d 279.

Sementara itu dalam Undang-Undang Kepailitan dan PKPU yang baru yaitu Undang-Undang Kepailitan dan PKPU Nomor 37 tahun 2004 berkaitan dengan PKPU sebagaimana diatur dalam Bab III yang terbagi menjadi dua bagian, yaitu: Bagian Pertama tentang Penundaan Kewajiban Pembayaran Utang beserta Akibatnya sebagaimana termuat 
E-ISSN : 2655-7347

dalam Pasal 222 s/d Pasal 264 kemudian Bagian Kedua: tentang Perdamaian yang termuat dalam Pasal 265 s/d Pasal 294. ${ }^{1)}$

Penundaan pembayaran utang atau dalam Bahasa inggrisnya disebut suspension of payment atau surseance van betaling merupakan suatu waktu atau masa yang diberikan oleh Undang-Undang berdasarkan putusan pengadilan dalam hal ini pengadilan niaga dimana dalam masa tersebut diberi kesempatan kepada pihak debitor dan kreditor untuk merundingkan cara-cara pembayaran utangnya dengan mengajukan suatu rencana perdamaian yang berisi rencana pembayaran baik sebagian atau seluruh utangnya, termasuk untuk merestrukturisasi utangnya apabila diperlukan. Jadi, penundaan kewajiban pembayaran utang sebenarnya merupakan sejenis moratorium, dalam hal ini legal moratorium. ${ }^{2)}$

Apabila dalam waktu yang bersamaan kepada pengadilan diajukan permohonan pernyataan pailit dan permohonan PKPU secara bersamaan, maka pengadilan niaga harus menjatuhkan putusan lebih dulu atas permohonan PKPU dibandingkan dengan permohonan pailit. Kemudian apabila ada permohonan PKPU yang diajukan setelah adanya permohonan pernyataan pailit yang telah diajukan terhadap debitor, maka agar permohonan PKPU ini dapat diputus lebih dahulu oleh pengadilan, maka permohonan PKPU tersebut harus diajukan pada sidang pertama pemeriksaan permohonan pernyataan pailit. Hal ini diatur dalam Pasal 229 Ayat (3) dan Ayat (4) Undang-Undang Kepailitan dan PKPU. ${ }^{3)}$

Pihak yang dapat mengajukan permohonan PKPU kepada pengadilam niaga adalah debitor yang tidak mampu atau yang memperkirakan bahwa dia tidak akan mampu untuk meneruskan pembayaran utangnya yang sudah jatuh tempo dan dapat ditagih kepada kreditor (lampiran Pasal 213 Undang-Undang Kepailitan dan PKPU). Akan tetapi, sebagaimana juga yang termuat di dalam Pasal 222 Ayat (1)

\footnotetext{
1) Rahayu Hartini, Hukum Kepailitan, Cetakan ke-3, (Malang: UMM Press, 2012), hal.157.

2) Munir Fuady, Hukum Pailit, Cetakan ke-5, (Bandung: Citra Aditya Bakti, 2014), hal.175.

3) Jono, Hukum Kepailitan, Cetakan ke-3, (Jakarta: Sinar Grafika, 2013), hal.170.
} 
Regina Nitami Kasdi \& F.X. Suyud Margono

ANALISIS PUTUSAN PENGADILAN NIAGA

Jurnal Hukum Adigamâ

TERKAIT AKIBAT HUKUM PERMOHONAN PKPU YANG

DIAJUKAN OLEH PIHAK YANG TIDAK

(STUDI KASUS PUTUSAN PENGADILAN NIAGA

PADA PENGADILAN NEGERI JAKARTA PUSAT

Volume 2 Nomor 2, Desember 2019

NOMOR 24/PDT.SUS-PKPU/2018/PN.NIAGA.JKT.PST)

E-ISSN : 2655-7347

Undang-Undang Kepailitan dan PKPU, pihak yang bisa mengajukan PKPU tidak hanya debitor melainkan juga kreditor. Selanjutnya di dalam Undang-Undang pula diatur bahwa apabila permohonan PKPU ini diajukan kepada debitor yang merupakan bank, Perusaan Efek, Bursa Efek, Lembaga Kliring dan Penjaminan, Lembaga Penyimpanan dan Penyelesaian, Perusahaan Asuransi, Perusahaan Reasuransi, Dana Pensiun, dan Badan Usaha Milik Negara yang bergerak di bidang kepentingan publik maka permohonan PKPU terhadap debitor-debitor ini mesti diajukan oleh badan atau lembaga sesuai dengan yang termuat di dalam Pasal 2 Ayat (3), Ayat (4), dan Ayat (5).

PKPU yang dimohonkan oleh debitor kepada pengadilan sebagaimana dimaksud dalam Pasal 3 Undang-Undang Kepailitan dan PKPU yang ditandatangani oleh debitor, kemudian oleh pemohon dan juga advokatnya (dalam Undang-Undang Nomor 4 Tahun 1998 disebut dengan penasehat hukum) kemudian harus disertai juga dengan daftar yang memuat sifat, jumlah piutang dan utang debitor beserta surat bukti secukupnya.

Selanjutnya apabila permohonan PKPU ini diajukan oleh kreditor maka, pengadilan niaga harus melakukan pemanggilan terhadap debitor melalui juru sita dengan surat kilat tercatat selambat-lambatnya 7 (tujuh) hari sebelum digelar persidangan dan debitor tetap harus menyerahkan daftar yang memuat sifat, jumlah piutang, dan utang debitor serta surat bukti yang dimiliki dan apabila ada, rencana perdamaian pada saat sidang PKPU tersebut berlangsung.

Pasal 224 Ayat (5) Undang-Undang Kepailitan dan PKPU mengatur bahwa rencana perdamaian bisa dimuat didalam lampiran dalam surat permohonan PKPU. Dalam Pasal 224 Ayat (6) Undang-Undang Kepailitan dan PKPU disebutkan, bahwa ketentuan di dalam Pasal 6 Ayat (1), Ayat (2), Ayat (3), Ayat (4), dan Ayat (5) berlaku mutatis mutandis 
Regina Nitami Kasdi \& F.X. Suyud Margono

ANALISIS PUTUSAN PENGADILAN NIAGA

Jurnal Huknem Adigamâ

TERKAIT AKIBAT HUKUM PERMOHONAN PKPU YANG

DIAJUKAN OLEH PIHAK YANG TIDAK

(STUDI KASUS PUTUSAN PENGADILAN NIAGA

PADA PENGADILAN NEGERI JAKARTA PUSAT

Volume 2 Nomor 2, Desember 2019

NOMOR 24/PDT.SUS-PKPU/2018/PN.NIAGA.JKT.PST)

E-ISSN : 2655-7347

sebagai tata cara pengajuan permohonan PKPU sesuai dengan yang termuat di dalam Ayat (1).

Dalam hal debitor merupakan termohon pailit maka debitor ini dapat memohon suatu PKPU kepada pengadilan pada saat persidangan pailit. Kemudian apabila Permohonan PKPU ini diajukan oleh sebuah Perseroan Terbatas (PT) maka permohonan PKPU atas prakarsa sendiri hanya dapat diajukan setelah mendapatkan izin atau persetujuan Rapat Umum Pemegang Saham atau yang biasanya disingkat dengan RUPS dengan kuorum kehadiran dan sahnya keputusan yang memenuhi jumlah diperlukan agar dapat diajukan suatu permohonan pailit bagi sebuah PT. ${ }^{4}$

Berdasarkan hal-hal yang telah Penulis kemukakan diatas dapat dilihat bahwa Undang-Undang Nomor 37 Tahun 2004 Tentang Kepailitan dan PKPU telah mengatur secara kongkrit pihak-pihak mana yang berwenang untuk mengajukan permohonan PKPU namun dalam kenyataannya masih didapatkan pengajuan permohonan PKPU yang dilakukan oleh pihak diluar yang sudah ditentukan dalam ketentuan Undang-Undang Nomor 37 Tahun 2004 Tentang Kepailitan dan Penundaan Kewajiban Pembayaran Utang.

Maka dari itu, Penulis memandang bahwa permasalahan mengenai kewenangan (Legal standing) para pihak untuk mengajukan permohonan PKPU terhadap Debitor perlu untuk diteliti guna mengetahui akibat hukum dari suatu permohanan PKPU yang diajukan oleh pihak yang tidak berwenang dan juga hal lainnya yang berkaitan dengan itu.

\section{B. Perumusan Masalah}

Bagaimana akibat hukum pengajuan permohonan PKPU yang diajukan oleh pihak yang tidak berwenang ditinjau dari Undang-Undang Nomor 37 Tahun 2004 Tentang Kepailitan dan Penundaan Kewajiban Pembayaran Utang? (Studi Kasus Putusan Pengadilan Niaga pada

\footnotetext{
4) Rahayu Hartini, Op.Cit., hal.158-159.
} 


\section{Jurnal Huknm Adigamâ}

Volume 2 Nomor 2, Desember 2019

E-ISSN : 2655-7347

Regina Nitami Kasdi \& F.X. Suyud Margono

ANALISIS PUTUSAN PENGADILAN NIAGA TERKAIT AKIBAT HUKUM PERMOHONAN PKPU YANG DIAJUKAN OLEH PIHAK YANG TIDAK (STUDI KASUS PUTUSAN PENGADILAN NIAGA PADA PENGADILAN NEGERI JAKARTA PUSAT NOMOR 24/PDT.SUS-PKPU/2018/PN.NIAGA.JKT.PST)

Pengadilan Negeri Jakarta Pusat Nomor 24/Pdt.SusPKPU/2018/PN.Niaga.Jkt.Pst)

\section{Metode Penelitian}

Metode Penelitian merupakan cara yang digunakan dalam rangka pengumpulan data, mengelola data, manganalisis data, serta menyimpulkan data sesuai dengan masalah yang akan di teliti oleh Penulis. Penelitian hukum bertujuan untuk mempelajari gajala hukum tertentu baik satu atau lebih gejala. Penelitian hukum dilakukan dengan serangkaian kegiatan ilmiah yang didasakan kepada metode, sistematikan serta suatu pemikiran tertentu. ${ }^{\text {5) }}$

1. Jenis Penelitian

Dalam penelitian ini, metode penelitian yang digunakan oleh Penulis adalah metode penelitian hukum normatif. Metode penelitan kepustakaan atau yang biasanya di sebut dengan Metode penelitian normatif merupakan suatu metode atau cara yang biasanya digunakan di dalam penelitian hukum yaitu yang dilakukan dengan cara meneliti bahan-bahan kepustakaan. ${ }^{6} \quad$ Dalam penelitian ini juga Penulis menggunakan dua pendekatan yaitu yang pertama pendekatan undang-undang yang dilakukan dengan menelaah semua regulasi dan undang-undang yang berkaitan dengan isu hukum yang dihadapi. ${ }^{7)}$ Yang kedua, pedekatan kasus yang dilakukan dengan menelaah kasuskasus berupa putusan pengadilan yang telah memiliki kekuatan hukum tetap dan mempunyai keterkaitan dengan permasalahan yang akan diteliti. ${ }^{8)}$ Pendekatan undang-undang yang digunakan oleh penulis yaitu Kitab Undang-Undang Hukum Perdata dan Undang-Undang

\footnotetext{
5) Sudarsono, Kamus Hukum: Edisi Baru, Cetakan ke-3. (Jakarta: Rineka Cipta, 2002), hal.52.

6) Soerjono Soekanto dan Sri Mamudi, Penelitian Hukum Normatif Suatu Tinjauan Singkat, Cetakan ke-11, (Jakarta: Raja Gravindo Persada, 2009), hal.13-14.

7) Peter Mahmud Marzuki Marzuki, Penelitian Hukum. Cetakan ke-13 (Jakarta: Kencana, 2017), hal. 133.

8) Ibid,. hal.134.
} 
Regina Nitami Kasdi \& F.X. Suyud Margono

ANALISIS PUTUSAN PENGADILAN NIAGA

Jurnal Hukum Adigamâ

TERKAIT AKIBAT HUKUM PERMOHONAN PKPU YANG

DIAJUKAN OLEH PIHAK YANG TIDAK

(STUDI KASUS PUTUSAN PENGADILAN NIAGA

PADA PENGADILAN NEGERI JAKARTA PUSAT

Volume 2 Nomor 2, Desember 2019

NOMOR 24/PDT.SUS-PKPU/2018/PN.NIAGA.JKT.PST)

E-ISSN : 2655-7347

No.37 Tahun 2004 Tentang Kepailitan dan Penundaan Kewajiban

Pembayaran Utang. Sedangkan pendekatan kasus yang digunakan dalam penelitian ini adalah studi kasus Putusan Pengadilan Niaga pada Pengadilan Negeri Jakarta Pusat No.24/Pdt.SusPKPU/2018/PN.Niaga.Jkt.Pst.

\section{Sifat Penelitian}

Sifat Penelitian yang digunakan oleh Penulis di dalam penelitian ini yaitu deskriptif. Maksud dari penelitian yang bersifat deskripstif adalah penulis dalam upaya untuk mencapai tujuan penelitian ini, berkeinginan untuk menggambarkan atau memaparkan subjek dan objek penelitian sesuai dengan hasil penelitian yang telah dilakukan.9

\section{Jenis Data}

Jenis data yang digunakan Penulis di dalam penelitian ini adalah data sekunder. Data sekunder adalah data yang didapatkan dari kegiatan penelahan kepustakan ataupun penelaahan berbagai literatur atau bahan kepustakaan yang memiliki keterkaitan yang erat dengan materi penelitan yang disebut dengan bahan hukum. ${ }^{10)}$ Berkaitan dengan hal ini data sekunder atau yang biasanya dikenal dengan istilah bahan hukum dalam penelitian hukum dibagi dalam tiga kelompok yaitu:

a. Bahan Hukum Primer

Bahan hukum primer yang mencakup peraturan perundangundangan, yurisprudensi, keputusan pengadilan dan perjanjian internasional. Bahan hukum ini bersifat otoritatif, yaitu tindakan yang dilakukan oleh lembaga yang berwewenang. ${ }^{11)}$ Bahan hukum primer yang digunakan oleh Penulis dalam penilitian ini adalah sebagai berikut:

1) Kitab Undang-Undang Hukum Perdata

\footnotetext{
9) Mukti Fajar dan Yulianto Achmad, Dualisme Penelitian Hukum Normatif \& Empiris, Cetakan ke-4. (Yogyakarta: Pustaka Pelajar, 2017), hal.183.

10) Ibid., hal.156.

11) Ibid., hal.157.
} 
Regina Nitami Kasdi \& F.X. Suyud Margono

ANALISIS PUTUSAN PENGADILAN NIAGA

Jurnal Huknm Adigamâ

TERKAIT AKIBAT HUKUM PERMOHONAN PKPU YANG

DIAJUKAN OLEH PIHAK YANG TIDAK

(STUDI KASUS PUTUSAN PENGADILAN NIAGA

PADA PENGADILAN NEGERI JAKARTA PUSAT

Volume 2 Nomor 2, Desember 2019

NOMOR 24/PDT.SUS-PKPU/2018/PN.NIAGA.JKT.PST)

E-ISSN : 2655-7347

2) Undang-Undang No.37 Tahun 2004 Tentang Kepailitan dan Penundaan Kewajiban Pembayaran Utang

3) Putusan Pengadilan Niaga pada Pengadilan Negeri Jakarta Pusat

No.24/Pdt.Sus-PKPU/2018/PN.Niaga.Jkt.Pst.

b. Bahan Hukum Sekunder

Bahan hukum sekunder sendiri merupakan bahan hukum yang bisa menjelaskan bahan hukum primer, bahan hukum sekunder ini meliputi rancangan perundang-undangan, hasil penelitian, bukubuku teks, jurnal ilmiah, surat kabar, pamflet, lefleat, brosur, dan berita internet. Kemudian bahan hukum sekunder yang digunakan oleh penulis dalam penelitian ini yaitu beberapa buku mengenai perikatan dan buku mengenai kepailitan dan PKPU. ${ }^{12)}$

c. Bahan Hukum Tersier

Bahan hukum tersier merupakan bahan hukum yang bisa memberikan pejelasan yang lebih jelas lagi baik terhadap bahan hukum primer maupun bahan hukum sekunder, yang termasuk bahan hukum ini yaitu kamus, ensiklopedia, leksikon, dan lainlain. ${ }^{13)}$

\section{Teknik Pengumpulan Data}

Teknik pengumpulan data yang dilakukan dalam penelitian hukum normatif yaitu dengan studi kepustakaan (liabrary research). Studi kepustakaan ini dilakukan dengan melakukan telusuran terhadap bahan-bahan hukum yaitu dengan membaca, melihat, mendengar, maupun dengan telusuran bahan hukum sebanyak banyak dari internet. ${ }^{14)}$

\section{Teknik Analisis Data}

Teknik analisis data dalam penelitian ini adalah teknik pendekatan kualitatif. Pendekatan kualitatif adalah data yang didapatkan melalui

\footnotetext{
12) Ibid., hal.157-158.

13) Ibid., hal.158.

14) Ibid., hal.193.
} 
Regina Nitami Kasdi \& F.X. Suyud Margono

ANALISIS PUTUSAN PENGADILAN NIAGA

Jurnal Hukum Adigamâ

TERKAIT AKIBAT HUKUM PERMOHONAN PKPU YANG

DIAJUKAN OLEH PIHAK YANG TIDAK

(STUDI KASUS PUTUSAN PENGADILAN NIAGA

PADA PENGADILAN NEGERI JAKARTA PUSAT

Volume 2 Nomor 2, Desember 2019

NOMOR 24/PDT.SUS-PKPU/2018/PN.NIAGA.JKT.PST)

E-ISSN : 2655-7347

penelitian kepustakaan, yang selanjutnya dianalisa secara kualitatif unutk memperoleh suatu kejelasan mengenai suatu permasalahan yang akan di teliti. Penulis harus dapat menentukan mana bahan hukum yang dapat digunakan di dalam penelitian ini yaitu yang mempunyai kualitas sebagai data dan mana bahan hukum yang tidak dapat digunak didalam penelitian ini dikarenakan tidak mempunyai relevansi dan keterkaitan dengan permasalahan yang sedang diteliti. ${ }^{15)}$

6. Teknik Pengolahan Data

Di dalam penelitian hukum ini Penulis juga melakukan pengolahan data yang berwujud kegiatan untuk mensistematisasi bahan-bahan hukum tertulis. Kemudian bahan-bahan tersebut diolah dengan cara menyeleksi data sekunder atau bahan hukum, dan dibuat pengelompokan sesuai dengan penggolongan bahan hukum dan yang terakhir data hasil penelitian tersebut kemudian disusun secara sistematis. Bahan-bahan hukum ini terdapat ketekaitan satu dengan yang lain untuk mendapatkan gambaran secara umum keseluruhan penelitian. ${ }^{16)}$

\section{PEMBAHASAN}

Pada bab ini Penulis akan memaparkan analisis permasalahan berkaitan dengan akibat hukum dari suatu permohonan PKPU yang diajukan oleh pihak yang tidak berwenang ditinjau dari Undang-Undang Nomor 37 Tahun 2004 Tentang Kepailitan dan Penundaan Kewajiban Pembayaran Utang (Studi Kasus Putusan Pengadilan Niaga pada Pengadilan Negeri Jakarta Pusat Nomor 24/Pdt.Sus-PKPU/2018/PN.Niaga.Jkt.Pst). Penulis akan memulai dengan definisi dari PKPU, Undang-Undang kepailitan dan PKPU tidak memuat secara tersurat pengertian dari PKPU, namun setelah melihat dan membaca pasal-pasal yang mengatur mengenai PKPU di dalam Undang-Undang

\footnotetext{
15) Ibid., hal.192.

16) Ibid., hal.181.
} 
E-ISSN : 2655-7347

Kepailitan dan PKPU, Penulis berkesimpulan bahwa PKPU dapat diartikan sebagai suatu upaya yang untuk mencapai mufakat antara debitor dan kreditor yang dilakukan dengan maksud untuk mengajukan rencana perdamaian dalam hal ini berupa penawaran pembayaran baik sebagian maupu seluruh utangnya yang sudah jatuh tempo kepada Kreditor berkenaan dengan penyelesaian utang piutang. Pasal 222 Ayat (2) Undang-Undang Kepailitan dan PKPU memberikan kesempatan debitor yaitu terhadap debitor yang tidak dapat atau memperkirakan sudah tidak dapat lagi meneruskan pembayaran utangutangnya yang sudah jatuh tempo dan dapat ditagih, debitor ini dapat memohonkan suatu penundaan kewajiban pembayaran utang. Pengertian mengenai PKPU juga disampaikan oleh Bapak Dr. Richard Adam, S.H., LL.M. yang menyatakan bahwa PKPU merupakan suatu kondisi atau situasi dimana debitor tidak membayar utangnya kepada kreditornya, sehingga debitor bisa memohonkan PKPU terhadap dirinya sendiri ataupun kreditornya yang memohonkan PKPU terhadap debitor dengan tujuan untuk mencapai suatu perdamaian, dengan mengumpulkan semua kreditor dan membicarakan mengenai cara-cara pembayaran utang serta merumuskan rencana perdamaian. Secara singkat, PKPU merupakan keadaan dimana debitor diberi kesempatan untuk mengajukan rencana perdamaian, dan apabila rencana perdamaian disetujui oleh kreditor maka rencana perdamian akan disahkan ini yang disebut dengan homologasi, sedangkan apabila rencana perdamaian di tolak maka terhadap debitor akan dinyatakan pailit. Dalam hal PKPU, debitor masih di beri kesempatan untuk mengajukan suatu rencara perdamaian yang berisi tata cara pembayaran utang-utangnya.

Kemudian Undang-Undang Kepailitan dan PKPU juga mengatur mengenai syarat sederhana yang harus dipenuhi untuk mengajukan kepailitan dan PKPU yaitu, pertama debitor harus memiliki dua orang Kreditor atau lebih, yang kedua tidak membayar lunas paling kurang satu utang yang sudah jatuh tempo dan dapat ditagih. Hal demikian termuat dalam Pasal 222 Ayat (1) UndangUndang Kepailitan dan PKPU yang menerangkan bahwa PKPU diajukan oleh 
E-ISSN : 2655-7347

debitor yang memiliki lebih dari 1 (satu) kreditor atau oleh kreditor dan Pasal 2 Ayat (1) Undang-Undang Kepailitan dan PKPU, menjelaskan bahwa terhadap debitor yang memilki lebih dari satu kreditor dan debitor tersebut tidak membayar paling sedikit satu utang yang telah jatuh tempo dan dapat ditagih, dijatuhkan pailit dengan putusan pengadilan, baik atas permohonan debitor sendiri maupun atas permohonan satu atau lebih kreditornya.

Selanjutnya, yang pelu diketahui bahwa Undang-Undang Kepailitan dan PKPU juga telah mengatur secara kongkrit pihak yang berwenang untuk mengajukan suatu permohonan PKPU yaitu Debitor dan Kreditor sesuai dengan yang termuat didalam Pasal 222 Ayat (1) Undang-Undang Kepailitan dan PKPU kemudian Pasal 223 Undang-Undang Kepailitan dan PKPU menerangkan bahwa Dalam hal debitor adalah bank, Perusahaan Efek, Bursa Efek, Lembaga Kliring dan Penjaminan, Lembaga Penyimpanan dan Penyelesaian, Perusahaan Asuransi, Perusahaan Reasuransi, Dana Pensiun, dan Badan Usaha Milik Negara yang bergerak di bidang kepentingan publik maka yang dapat mengajukan permohonan penundaan kewajiban pembayaran utang adalah lembaga sebagaimana dimaksud dalam Pasal 2 Ayat (3), Ayat (4), dan Ayat (5). Dimana Pasal 2 Ayat (3), Ayat (4), dan Ayat (5) Undang-Undang Kepailitan dan PKPU menjelaskan bahwa Permohonan kepailitan dan PKPU bisa diajukan oleh kejaksaan untuk kepentingan umum, jika debitornya merupakan sebuah bank, permohonan pailit hanya dapat diajukan oleh Bank Indonesia, jika debitor merupakan Perusahaan Efek, Bursa Efek, Lembaga Kliring dan Penjaminan, Lembaga Penyimpanan dan Penyelesaian, permohonan pernyataan pailit hanya dapat diajukan oleh Badan Pengawas Pasar Modal, yang saat ini fungsi dan kewenangannya dialihkan kepada lembaga Otoritas Jasa Keuangan sebagaimana yang diatur dalam dengan Pasal 55 Ayat 1 Undang-Undang No. 21 Tahun 2011 Tentang Otoritas Jasa Keuangan, dan yang terakhir jika debitor adalah Perusahaan Asuransi, Perusahaan Reasuransi, Dana Pensiun, atau Badan Usaha Milik Negara yang bergerak di bidang kepentingan publik, permohonan pernyataan pailit hanya 
Regina Nitami Kasdi \& F.X. Suyud Margono

ANALISIS PUTUSAN PENGADILAN NIAGA

E-ISSN : 2655-7347

dapat diajukan oleh Menteri Keuangan. Dengan demikian, dapat dilihat bahwa Undang-Undang telah memberikan batasan yang tegas terhadap siapa saja yang berwenang untuk mengajukan Kepailitan dan PKPU.

Berkaitan dengan pihak yang berwenang untuk mengajukan PKPU ini juga, Penulis telah menanyakan pendapat dari Bapak. V. Harlen Sinaga, S.H., M.H. yang menyatakan bahwa pada dasarnya yang dapat mengajukan permohonannya adalah pihak yang memiliki kepentingan atau memiliki hak untuk itu. Jadi menurut Penulis pihak yang berhak untuk mengajukan permohonan PKPU ini merupakan pihak yang secara langsung mempunyai kepentingan terhadap utang piutang yang menjadi dasar diajukannya PKPU dan pihak yang sesuai dengan yang termuat di dalam Pasal 222 Ayat (1) dan Pasal 223 Undang-Undang Kepailitan dan PKPU. pendapat Penulis ini telah diperkuat dengan pendapat Bapak Dr. Richard Adam, S.H., LL.M. yang juga menyatakan bahwa dikarenakan Undang-Undang telah jelas mengatur siapa saja pihak yang berhak untuk mengajukan permohonan PKPU maka dari itu, suatu permohonan PKPU tidak dapat diajukan oleh pihak diluar dari yang telah ditentukan didalam Undang-Undang.

Berdasarkan Putusan Pengadilan Niaga pada Pengadilan Negeri Jakarta Pusat Nomor 24/Pdt.Sus-PKPU/2018/PN.Niaga.Jkt.Pst. Dengan mana terdapat pihak-pihak yang berperkara yaitu PT. ALUVINDO EXTRUSION sebagai Pemohon PKPU I dan PT. SRIMURNI SURABAYA sebagai Pemohon PKPU II, yang secara bersama-sama mengajukan permohonan PKPU terhadap PT. JAYA BERSAUDARA sebagai Termohon PKPU. Kemudian yang menjadi awal permasalahan di anatara para pihak ini yaitu PT. ALUVINDO EXTRUSION dan PT. SRIMURNI SURABAYA menyatakan bahwa PT JAYA BERSAUDARA memilki utang yang sudah jatuh tempo dan dapat ditagih kepada mereka. PT ALUVINDO EXTRUSION menjelaskan bahwa pada tahun 2015, PT. JAYA BERSAUDARA memesan lembar aluminium di perusahaannya. Kemudian pihaknya telah mengirimkan barangnya serta menyampaikan tagihan (invoce) kepada PT. JAYA BERSAUDARA. Namun 
PT JAYA BERSAUDARA tidak kunjung membayar tagihannya tersebut. PT. ALUVINOD EXTRUSION telah berkali-kali mengajukan tagihan kepada PT JAYA BERSAUDARA untuk segera membayar utang-utangnya yang sudah jatuh waktu. PT. ALUVINDO EXTRUSION berkali-kali memperingatkan PT. JAYA BERSAUDARA baik secara lisan maupun tertulis untuk segera melunasi utang-utangnya kepada PT. ALUVINDO EXTRUSION, namun PT. JAYA BERSAUDARA tidak mengindahkan peringatan ini.

Hal yang sama juga dinyatakan oleh PT. SRIMURNI SURABAYA. Pihaknya menyatakan bahwa di tahun yang sama, PT. JAYA BERSAUDARA juga memesan lembar aluminium kepada perusahaannya, kemudian PT. SRIMURNI SURABAYA telah mengirimkan barangnya dan sudah diterima oleh PT. JAYA BERSAUDARA. Selanjutnya, PT. SRIMURNI SURABAYA telah menyampaikan tagihan (invoce) kepada PT. JAYA BERSAUDARA dan PT. SRIMURNI SURABAYA telah berkali kali memohon kepada PT. JAYA BERSAUDARA untuk segera melunasi utang-utangnya kepada PT. SRIMURNI SURABAYA, namun PT. JAYA BERSAUDARA sama sekali tidak mengindahkan permohonan tersebut. Maka dari itu, pada tanggal 22 Februari 2018, PT. ALUVINDO EXTRUSION dan PT. SRIMURNI SURABAYA mengajukan permohonan PKPU terhadap PT. JAYA BERSAUDARA dan mendaftarkannya di Kepaniteraan Pengadilan Niaga pada Pengadilan Negeri Jakarta Pusat.

Kemudian, PT. ALIVINDO EXTRUSION yang dalam proses persidangan mendalilkan bahwa PT. JAYA BERSAUDARA mempunyai utang kepada perusahannya membuktikan adanya hubungan hukum diantara mereka idengan surat tagihan atau invoce yang memuat jumlah tagihan yang harus dibayar oleh PT.JAYA BERSAUDARA terhadapa perusahaannya beserta dengan beberapa bukti lain seperti surat peringatan yang dikirimkan oleh PT. ALUVINDO EXTRUSION kepada PT. JAYA BERSAUDARA namun tidak diindahkan oleh PT JAYA BERSAUDARA 
Regina Nitami Kasdi \& F.X. Suyud Margono

ANALISIS PUTUSAN PENGADILAN NIAGA

Selanjutnya dalam proses persidangan PT. SRIMURNI SURABAYA menyatakan bahwa perusahaanya yang bergerak di bidang distribusi perdagangan aluminium biasanya dikenal dengan sebutan SRIMURNI ALUMINIUM. Namun, berdasarkan dokumen-dokumen yang diperoleh Penulis yang terdiri dari Surat Izin Usaha Perdagangan (Mikro) Nomor: 503/155.A/436.6.11/2014, Tanda Daftar Perusahaan Nomor: 13.01.5.47.54018, dan NPWP Nomor: 07.181.489.1.614.001 atas nama Ali Handoko, menunjukan bahwa SRIMURNI ALUMINIUN merupakan badan usaha yang berdiri sendiri dan terpisah dari PT. SIRMURNI SURABAYA. Badan usaha yang dinamakan dengan SRIMURNI SURABAYA merupakan badan berbentuk usaha dagang atau biasanya disingkat dengan UD dengan nama UD SRIMURNI ALUMINIUM yang beralamat di jalan Tembaan No. 57 Kel. Gundih Kec. Bubutan Surabaya dengan penanggung jawab Bapak Ali Handoko, perusahaan ini bergerak di bidang usaha perdagangan aluminium.

Maka dari itu, jelaslah bahwa PT. SRIMURNI SURABAYA dan UD SRIMURNI ALUMINIUM merupakan dua badan usaha yang berbeda dan masing-masing berdiri sendiri. Selanjutnya, seperti yang telah dipaparkan sebelumnya bahwa pihak-pihak yang mengajukan Permohonan PKPU terhadap PT. JAYA BERSAUDARA adalah PT. ALUVINDO EXTRUSION dan PT. SRIMURNI SURABAYA, dengan mana kedua perusahaan ini menyatakan bahwa PT JAYA BERSAUDARA memiliki kewajiban utang yang sudah jatuh tempo kepada mereka dan wajib untuk dilunasi maka dari itu, mereka mengajukan permohonan PKPU sebagai upaya untuk mendapatkan pelunasan utang ini dari PT JAYA BERSAUDARA. Namun setelah Penulis melakukan pencarian data terkait dengan permasalahan ini, Penulis menemukan dokumendokumen yang menunjukan bahwa terdapat hal yang tidak wajar di dalam permohonan PKPU yang diajukan oleh PT ALUVINDO EXTRUSION dan PT SRIMURNI SURABAYA yaitu berdasarkan surat tagihan (sales invoce), sales order, purchase order, dan surat jalan yang digunakan sebagai bukti untuk membuktikan adalah hubungan hukum diantara para pihak menunjukan bahwa 
E-ISSN : 2655-7347

hubungan hukum yang terbit dari peristiwa hukum jual beli lembar aluminium ini adalah diantara PT. JAYA BERSAUDARA dengan UD. SRIMURNI ALUMINIUM dan bukan dengan PT. SRIMURNI SURABAYA. Sedangkan, sesuai dengan yang telah penulis paparkan sebelumnya bahwa PT. SRIMURNI SURABAYA dan UD. SRIMURNI ALUMINIUM merupakan dua badan usaha yang masing-masing berdiri sendiri sehingga menurut pendapat Penulis, jika dikaitkan dengan ketentuan di dalam Pasal 222 Ayat (1) Undang-undang Kepailitan dan PKPU yang mengatur mengenai pihak-pihak yang berwenang untuk mengajukan permohonan PKPU sebagaimana yang telah disebutkan diatas, seharusnya PT. SRIMURNI SURABAYA tidak mempunyai wewenang untuk mengajukan permohonan PKPU terhadap PT. JAYA BERSAUDARA dikarenakan hubungan hukum yang terjalin sebagai dasar diajukannya permohonan PKPU yaitu diantara PT JAYA BERSAUDARA dengan UD SRIMURNI ALUMINIUM. Dengan demikian artinya PT. SRIMURNI SURABAYA tidak dapat membuktikan hubungan hukum yang menjadi dasar terbitnya utang piutang diantara perusahaannya dengan PT. JAYA BERSAUDARA.

Kemudian, berkaitan dengan surat tagihan (sales invoce), sales order, purchase order, dan surat jalan yang digunakan sebagai bukti adanya hubungan hukum diantara para pihak didalam perkara PKPU, Penulis berpendapat bahwa dokumen-dokumen seperti ini dapat digunakan sebagai pembuktian di persidangan dikarenakan dokumen-dokumen seperti ini memang lazim dipakai oleh para pihak dalam melaksanakan suatu transaksi jual beli dalam praktik sehari-hari, tanpa membuat suatu perjanjian jual beli lagi. Dan didalam kenyataannya hakim menerima pembuktian dengan dokumen-dokumen ini karena dalam pemeriksaan suatu perkara dipengadilan, hakin juga harus menyesuaikannya dengan kebiasaan bisnis yang ada. Pendapat penulis ini diperkuat dengan pendapat dari Bapak Dr. Richard Adam, S.H., LL.M. yang menyatakan bahwa dokumen-dokumen semacam ini juga dapat dijadikan bukti untuk membuktikan adanya suatu peristiwa hukum yang 
E-ISSN : 2655-7347

dijadikan dasar diajukannya suatu permohonan PKPU. Namun, dokumendokumen ini harus saling melengkapi untuk membuktikan telah terjadi suatu peristiwa hukum, apabila pihak dalam suatu perkara dapat menunjukan dokumen-dokumen ini secara lengkap maka kekuatan pembuktiannya sama dengan perjanjian. Kemudian pendapat ini diperkuat lagi dengan pendapat Bapak Nixon D. H. Sipahutar, S.H., MBA. yang menyatakan bahwa hubungan hukum diantara para pihak dalam suatu jual beli dapat dibuktikan dengan dokumen berupa purchase order, karena purchase order atau biasa disingkat dengan PO dapat dipersamakan dengan perjanjian jual beli, sedangkan jika hanya sales order, sales invoce, atau surat jalan belum dapat membuktikan adanya suatu hubungan hukum diataran para pihak. Jadi Penulis menarik kesimpulan bahwa apabila pihak-pihak dalam permohonan PKPU ini mengajukan bukti-bukti berupa dokumen-dokumen yang telah penulis sebutkan diatas maka pembuktiannya dapat disamakan dengan suatu perjanjian secara tertulis. Seperti yang telah Penulis paparkan sebelumnya bahwa pengadilan harus menerima pembuktian dengan dokumen-dokumen ini karena dalam pemeriksaan suatu perkara di pengadilan hakim harus menyesuaikan dengan kebiasaan bisnis yang terjadi sehari-hari dalam dunia bisni.

Selanjutnya sesuai dengan yang telah Penulis jelaskan sebelumnya bahwa Penulis berpendapat bahwa PT. SRIMURNI SURABAYA tidak memiliki legal standing/kedudukan hukum untuk mengajukan permohonan PKPU terhadap PT. JAYA BERSAUDARA, karena hal ini bertentangan dengan Pasal 222 Ayat (1) Undang-Undang Kepailitan dan PKPU yang menyatakan bahwa yang dapat mengajukan permohonan PKPU hanyalah Kreditor ataupun Debitor yang memiliki hak dan kepentingan terhadap utang piutang tersebut. Dengan demikian dikarenakan PT. SRIMURNI SURABAYA ini bukan merupakan pihak yang berwenang untuk mengajukan Permohonan PKPU terhadapa PT. JAYA BERSAUDARA, maka terhadap permohonan PKPU yang diajukan oleh PT. ALUVINDO EXTRUSION dan PT. SRIMURNI SURABAYA terhadap PT. JAYA BERSAUDARA ini harus dinyatakan permohonan tidak dapat 
diterima oleh pengadilan yang berwenang untuk memeriksa dan memutus perkara ini karena bertentangan dengan ketentuan yang telah diatur dalam Undang-Undang Kepailitan dan PKPU. Pendapat penulis ini diperkuat dengan pendapat dari Bapak V. Harlen Sinaga, S.H., M.H. yang menyatakan bahwa apabila ada permohonan kepailitan atau PKPU yang diajukan oleh pihak yang tidak memiliki kedudukan hukum/legal standing artinya tidak sesuai dengan yang ditentukan dalam undang-undang maka terhadap permohonan tersebut harusnya dinyatakan tidak dapat diterima oleh hakim yang memeriksa perkara tersebut.

Namun pada kenyataannya dalam kasus ini, hakim pengadilan niaga yang memeriksa perkara ini mengabulkan permohonan dari para pemohon yaitu PT. ALUVINDO EXTRUSION dan PT. SRIMURNI SURABAYA yang disampaikan melalui Putusan Pengadilan Niaga pada Pengadilan Negeri Jakarta Pusat Nomor 24/Pdt.Sus-PKPU/2018/PN.Niaga.Jkt.Pst. Berdasarkan putusan ini PT. JAYA BERSAUDARA ditetapkan berada dalam keadaan PKPU sementara dan pengadilan juga mengangkat beberapa orang pengurus PKPU yang bertugas untuk membantu debitor dan kreditor untuk memusyawarakan cara-cara pembayaran utangnya. Penulis kurang sependapat dengan putusan pengadilan niaga tersebut dikarenakan berdasarkan invoce dan alat bukti lainnya yang sudah disebutkan diatas, sudah jelas bahwa PT SRIMURNI SURABAYA tidak memiliki kedudukan hukum/legal standing untuk mengajukan permohonan PKPU, menurut pendapat penulis hal ini juga berakibat tidak terpenuhinya syarat pembuktian sederhana sesuai dengan yang telah ditentukan di dalam Undang-Undang Kepailitan dan PKPU yang menyatakan dalam suatu permohonan PKPU harus terdapat lebih dari satu kreditor dan minimal satu utangnya telah jatuh tempo dan dapat ditagih. Maka dari itu terhadap permohonan PKPU yang diajukan oleh pihak diluar yang telah ditentukan didalan Pasal 222 Ayat (1) dan Pasal 223 UU Kepailitan dan PKPU seharusnya hakim menyatakan permohonan ini tidak dapat diterima. Pendapat penulis diperkuat dengan pendapat Bapat V. Harlen Sinaga S.H., 
E-ISSN : 2655-7347

M.H. yang menjelaskan bahwa syarat sederhana menurut Beliau adalah pembuktian yang sangat singkat yaitu dari segi waktunya pembuktian ini tidak memakan waktu yang lama. Dimana terdapat utang dagang yang tertentu jumlahnya, tertentu waktunya dan harus dipenuhi debitor. Artinya maksud dari pembuktian sederhana adalah para pihak cukup membuktikan adanya legal relation atau hubungan hukum diantara para pihak dalam suatu kepailitan atau PKPU yang terbit karena suatu perikatan atau peristiwa hukum sebelumnya. Menurut Penulis mengingat perkara kepailitan dan PKPU berjiwa harus diselesaikan dalam waktu yang singkat dan cepat maka apabila para pihak tidak dapat membuktikan hubungan kerjasama atau adanya utang piutang diantara mereka maka pembuktian ini harus dipandang sebagai pembuktian yang tidak sederhana lagi dan hakim wajib menyatakan permohonan tersebut tidak dapat diterima. Pendapat Penulis ini diperkuat dengan penjelasan dari Bapak Valentino Revol Korompis, S.H., M.Kn. yang menyatakan bahwa pada prinsipnya setiap pengajuan permohonan PKPU harus diajukan oleh pihak yang memiliki legal standing jadi akibat hukum dari suatu permohonan PKPU diajukan oleh pihak yang tidak memiliki legal standing adalah permohonan tersebut wajib untuk ditolak oleh Majelis Hakim yang memeriksa perkara karena bertentangangan dengan ketentuan dalam UU Kepailitan dan PKPU.

Selanjutnya, terhadap Putusan hakim yang mengabulkan permohonan PKPU dalam kasus ini Penulis melihat bahwa terdapat kekhilafan atau kekeliruan yang dilakukan oleh hakim pemeriksa perkara ini dalam pemeriksaan bukti-bukti yang ada, sehinggah hakim dapat menerima serta mengabulkan permohonan dari para pemohon PKPU dalam kasus ini. Pendapat Penulis ini diperkuat dengan Pendapat yang disampaikan oleh Bapak Nixon D. H. Sipahutar, S.H., MBA. Yang menyatakan bahwa menyatakan bahwa dalam hal terjadi kasus dimana hakim pengadilan niaga mengabulkan permohonan PKPU, sedangkan dalam permohonan tersebut pemohon tidak dapat membuktikan hubungan hukum diantara mereka dan pembuktiannya tidak 
Regina Nitami Kasdi \& F.X. Suyud Margono

ANALISIS PUTUSAN PENGADILAN NIAGA

Jurnal Hukum Adigamâ

TERKAIT AKIBAT HUKUM PERMOHONAN PKPU YANG

DIAJUKAN OLEH PIHAK YANG TIDAK

(STUDI KASUS PUTUSAN PENGADILAN NIAGA

PADA PENGADILAN NEGERI JAKARTA PUSAT

Volume 2 Nomor 2, Desember 2019

E-ISSN : 2655-7347

sederhana, artinya hakim dalam menjatuhkan putusannya telah melakukan suatu kekeliruan yang nyata.

Menurut pendapat Penulis seharusnya dalam keadaan seperti ini pihak yang merasa dirugikan berdasarkan putusan hakim yang mengandung kekeliruan seperti ini harus mengajukan upaya hukum lagi sebagai suatu bentuk upaya yang dilakukan untuk memperjuangkan keadilan namun, yang menjadi kendalanya adalah di dalam Undang-Undang Kepailitan dan PKPU telah dinyatakan secara tegas bahwa terhadap Putusan PKPU tidak dapat diajukan upaya hukum apapun yaitu yang termuat di dalam Pasal 235 UndangUndang Kepailitan dan PKPU, maka dari itu Putusan PKPU yang dikeluarkan oleh Pengadilan Niaga ini merupakan putusan yang telah berkekuatan hukum tetap. Menurut pendapat penulis, seharusnya dalam hal terjadi kekeliruan hakim dalam pengambilan suatu keputusan maka terhadap pihak yang dirugikan harus diberikan suatu jalan keluar untuk dapat memperjuangkan suatu keadilan khusunya bagi dirinya sendiri. Bapak Dr. Richard Adam, S.H., LL.M. juga menyampaikan pendapat yang memperkuat pendapat dari Penulis ini yang menyatakan bahwa regulasi mengenai Kepailitan dan PKPU yang ada sekarang ini sudah cukup melindungi hak-hak dari para kreditor dan debitor namun akan lebih baik lagi apabila Undang-Undang mengatur adanya suatu upaya hukum yang dapat ditempuh oleh pihak yang kalah terhadap suatu putusan PKPU, dikarenakan hakim bagaimanapun adalah manusia biasa yang tidak terlepas dari kesalahan. Sehingga apabila dalam suatu pengambilan putusan PKPU, hakim melakukan kekeliruan atau kekhilafan yang nyata, para pihak diberikan exit atau jalan keluar oleh undang-undang berkaitan dengan masalah tersebut. Artinya, bisa saja untuk memberikan kemungkian bagi pihak yang dirugikan dari suatu putusan PKPU yang keliru mengajukan upaya hukum haruslah dilakukan revisi terhadap Undang-Undang Kepailitan dan PKPU yang ada sekarang ini yaitu dengan menambahkan suatu ketentuan yang mengatur lebih lanjut jalan keluar yang dapat ditempuh oleh pihak yang dirugikan dari suatu keputusan PKPU yang keliru. Akan tetapi Penulis 
E-ISSN : 2655-7347

menyadari bahwa untuk melakukan suatu perubahan terhadap suatu undangundang bukanlah suatu hal yang mudah harus melalui proses yang panjang dan mengumpulkan berbagai pendapat dan pemikiran dari para ahli dari berbagai bidang khususnya ahli di bidang Kepialitan dan PKPU yang ada di Indonesia namun, tetap saja bukan tidak mungkin di masa yang akan datang dilakukan perubahan terhadap Undang-Undang Kepailitan dan PKPU kemudian bagian dari perubahan ini adalah undang-undang akan mengfasilitasi mengenai upaya hukum yang dapat diajukan oleh pihak yang kalah terhadap suatu putusan PKPU yang dikeluarkan oleh Pengadilan Niaga.

Menjawab permasalahan yang diangkat oleh Penulis yaitu yang berkaitan dengan akibat hukum pengajuan permohonan PKPU yang diajukan oleh pihak yang tidak berwenang ditinjau dari Undang-Undang Nomor 37 Tahun 2004 Tentang Kepailitan dan Penundaan Kewajiban Pembayaran Utang maka Penulis menyatakan bahwa terhadap permohonan tersebut harus dinyatakan tidak dapat diterima oleh hakim yang berwenang memeriksa perkara tersebut, karena permohonan tersebut bertentangan dengan norma tertulis sebagaimana yang telah termuat didalam Pasal 222 Ayat (1) Undang-Undang Kepailitan dan PKPU.

\section{PENUTUP}

\section{A. Kesimpulan}

Berdasarkan uraian hasil analisis mengenai permasalahan dan pemaparan yang telah Penulis diuraikan pada bab-bab terdahulu, maka Penulis menarik kesimpulan sebagai berikut yaitu penundaan kewajiban pembayaran utang atau yang biasanya disingkat dengan PKPU merupakan salah satu upaya yang dapat dilakukan oleh debitor dan kreditor untuk menyelesaikan sengketa utang piutang diantara mereka yang dilakukan dengan pengajuan suatu rencana perdamaian yang meliputi penawaran pembayaran baik jumlah keseluruhan utangnya kepada Kreditor atau sebagiannya yang berkenaan dengan penyelesaian 
Regina Nitami Kasdi \& F.X. Suyud Margono

ANALISIS PUTUSAN PENGADILAN NIAGA

utang piutang di antara mereka. Di dalam Undang-Undang No. 37 Tahun 2004 Tentang Kepailitan dan PKPU diatur secara spesifik mengenai pihak yang berwenang untuk mengajukan permohonan PKPU. Pengajuan permohonan PKPU dapat dilakukan oleh baik Debitor atau Kreditor hal ini sesuai dengan yang diatur di dalam Pasal 222 Ayat (1) UU KPKPU Kemudian diatur juga apabila permohonan PKPU diajukan kepada badan/lembaga tertentu sebagaimana yang termuat di dalam Pasal 223 UU KPKPU maka lembaga atau badan yang berwenang untuk mengajukan permohonan PKPU adalah badan atau lembaga yang disebutkan dalam Pasal 2 Ayat (3), Ayat (4), dan Ayat (5) UU KPKPU. Berkaitan dengan adanya ketentuan ini, Penulis kurang sependapat dengan Putusan Pengadilan Niaga pada Pengadilan Negeri Jakarta Pusat Nomor 24/Pdt.Sus-PKPU/2018/PN.Niaga.Jkt.Pst. yang mengabulkan permohonan PKPU yang diajukan oleh PT. SRIMURNI SURABAYA dan PT. ALUVINDO EXTRUSION terhadap PT. JAYA BERSAUDARA dikarenakan Penulis berpendapat bahwa PT. SRIMURNI SURABAYA tidak memilki legal standing/kedudukan hukum untuk mengajukan permohonan PKPU sebab tidak semua pihak boleh mengajukan permohonan PKPU, hanya pihak-pihak sebagaimana yang telah disebutkan di dalam Pasal 222 Ayat (1) dan Pasal 223 Undang-Undang Kepailitan dan PKPU yang memiliki wewenang untuk mengajukan permohonan PKPU ini. Menurut Penulis, berdasarkan dokumen-dokumen yang diperoleh Penulis pada saat Penulis mencari data untuk meneliti permasalahan ini, pihak yang memiliki kedudukan hukum/legal standing untuk mengajukan permohonan PKPU dalam kasus ini adalah PT. ALUVINDO EXTRUSION dan UD. SRIMURNI ALUMINIUM maka dari itu Penulis berpendapat seharusnya kedua perusahaan inilah yang mengajukan permohoanan PKPU terhadap PT. JAYA BERSAUDARA dalam kasus ini. Namun, dikarenakan permohonan ini diajukan salah satunya oleh pihak yang tidak memiliki 
Regina Nitami Kasdi \& F.X. Suyud Margono

ANALISIS PUTUSAN PENGADILAN NIAGA

Jurnal Hukum Adigamâ

TERKAIT AKIBAT HUKUM PERMOHONAN PKPU YANG

DIAJUKAN OLEH PIHAK YANG TIDAK

(STUDI KASUS PUTUSAN PENGADILAN NIAGA

PADA PENGADILAN NEGERI JAKARTA PUSAT

Volume 2 Nomor 2, Desember 2019

NOMOR 24/PDT.SUS-PKPU/2018/PN.NIAGA.JKT.PST)

E-ISSN : 2655-7347

kedudukan hukum atau legal standing untuk itu maka Pengadilan yang memeriksa perkara ini seharunya menyatakan terhadap permohonan PKPU tersebut tidak dapat diterima karena bertentangan dengan norma hukum yang termuat di dalan Undang-Undang No. 37 Tahun 2007 tentang Kepailitan dan PKPU. Penulis berpendapat bahwa terhadap putusan Pengadilan Niaga pada Pengadilan Negeri Jakarta Pusat Nomor 24/Pdt.Sus-PKPU/2018/PN.Niaga.Jkt.Pst. hakim pengadilan niaga yang memeriksa dan memutus perkara ini telah melakukan suatu kekhilafan atau kekeliruan yang nyata dan membawa kerugian terhadap pihak Termohon PKPU yang pada akhirnya berada dalam kondisi PKPU sementara, dan pihak yang kalah ini, tidak dapat mengajukan upaya hukum lagi dikarenakan terhadap suatu Putusan PKPU tidak terdapat upaya hukum apapaun yang bisa dilakukan sebagaimana telah termuat di dalam Pasal 235 Undang-Undang Kepailitan dan PKPU.

\section{B. Saran}

Berdasarkan kesimpulan yang telah dipaparkan diatas maka Penulis akan memberikan beberapa saran sebagai berikut yaitu kepada pihak yang terkait, bahwa seharusnya dari awal yang mengajukan permohonan PKPU terhadap PT. JAYA BERSAUDARA adalah PT. ALUVINDO EXTRUSION dan UD STIMURNI ALUMINIUM, karena dari awal jelas dua perusahaan ini lah yang memiliki tagihan utang kepada PT. JAYA BERSAUDARA berdasarkan surat tagihan (invoce), purchase order, sales order, dan surat jalan yang digunakan sebagai bukti untuk membuktikan hubungan hukum yang menjadi dasar diajukannya permohonan PKPU. Dan kepada PT. SRIMURNI SURABAYA seharusnya lebih jujur dan terbuka mengakui bahwa dia merupakan badan usaha yang berdiri sendiri dan terpisah dari UD SRIMURNI ALUMIUM sehingga perusahaannya tidak seharusnya mengajukan Permohonan PKPU terhadap PT. JAYA BERSAUDARA. Pihak-pihak 
dalam perkara ini harus lebih menjunjung tinggi nilai-nilai kejujuran dan keterbukaan dalam membatu proses pemeriksaan perkara di pengadilan. Kepada PT. JAYA BERSAUDARA dikarenakan tidak terdapat upaya hukum yang dapat dilakukan oleh PT. JAYA BERSAUDARA untuk membatalkan putusan PKPU ini maka PT. JAYA BERSAUDARA sebaiknya tetap menghargai dan menghormati putusan pengadilan ini dan melaksanakannya dengan lapang dada.

Kepada Penegak Hukum khususnya hakim, dalam memeriksa, mengadili dan memutus perkara hakim harus lebih jelih melihat dan memeriksa bukti-bukti yang ada agar hakim dapat menghasilkan suatu putusan yang baik dan benar. Kemudian karena hakim merupakan pejabat yang di beri kewenanngan dan independensi yang tinggi yang diberikan oleh negara untuk melaksanakan tugasnya maka hakim haruslah menggunakan segala kewenanganya ini dengan baik dan menjunjung tinggi nilai-nilai moral dan keadilan untuk memutus suatu perkara yang diperiksa olehnya. Walaupun memang secara keseluruhan pengadilan telah melaksanakan fungsinya dengan baik namun memang dalam kasus-kasus tertentu masih didapati kesalahan atau kekeliruan hakim dalam pengambilan keputusan dimana dalam pengambilan keputusannya hakim tidak mendasarkan pada ketentuan atau aturan hukum yang berlaku. Maka dari itu, untuk menghindari hal-hal tersebut, Penulis menyarankan harus ada peningkatan kualitas dari segi hakimnya dengan adanya pendidikan berkelanjutan bagi hakim.

Kepada pembuat undang-undang, khusunya berkaitan dengan pembuatan Undang-Undang No.37 Tahun 2004 Tentang Kepailitan dan PKPU, bahwa memang regulasi mengenai Kepailitan dan PKPU yang ada sekarang ini sudah cukup melindungi hak-hak dari para kreditor dan debitor namun Penulis menyarankan bahwa akan lebih baik lagi apabila pembuat undang-undang membuat suatu peraturan yang mengatur lebih lanjut hal yang harus dilakukan oleh pihak yang kalah berdasarkan suatu 
Jurnal Huknm Adigamä

Volume 2 Nomor 2, Desember 2019

E-ISSN : 2655-7347
Regina Nitami Kasdi \& F.X. Suyud Margono

ANALISIS PUTUSAN PENGADILAN NIAGA TERKAIT AKIBAT HUKUM PERMOHONAN PKPU YANG DIAJUKAN OLEH PIHAK YANG TIDAK (STUDI KASUS PUTUSAN PENGADILAN NIAGA PADA PENGADILAN NEGERI JAKARTA PUSAT NOMOR 24/PDT.SUS-PKPU/2018/PN.NIAGA.JKT.PST)

putusan PKPU yang keliru, dikarenakan hakim bagaimanapun hanyalah manusia biasa yang tidak luput dari kesalahan dan kekeliruan. Sehingga apabila dalam suatu pengambilan putusan PKPU, hakim melakukan kekeliruan atau kekhilafan yang nyata, para pihak diberikan exit atau jalan keluar oleh undang-undang berkaitan dengan masalah tersebut.

Kepada masyarakat, Penulis menyarakan agar lebih berhati-hati dalam mengajukan suatu permohonan kepada pengadilan harus di cermati mengenai kepentingan atau haknya untuk mengajukan permohonan tersebut karena pada dasarnya setiap orang yang memohonkan sesuatu kepada pengadilan wajib mempunyai kepentingan didalamnya.

\section{DAFTAR PUSTAKA}

\section{A. Buku}

Fajar, Mukti dan Yulianto Achmad, Dualisme Penelitian Hukum Normatif \& Empiris. Cetakan ke-4. (Yogyakarta: Pustaka Pelajar, 2017.)

Fuady, Munir. Hukum Pailit. Cetakan ke-5. (Bandung: Citra Aditya Bakti, 2014.)

Hartini, Rahayu. Hukum Kepailitan. Cetakan ke-3. (Malang: UMM Press, 2012.)

Jono. Hukum Kepailitan. Cetakan ke-3. (Jakarta: Sinar Grafika, 2013.)

Marzuki, Peter Mahmud. Penelitian Hukum. Cetakan ke-13 (Jakarta: Kencana, 2017.)

Soekanto, Soerjono dan Sri Mamudi. Penelitian Hukum Normatif Suatu Tinjauan Singkat, Cetakan ke-11. (Jakarta: Raja Gravindo Persada, 2009.)

Sudarsono. Kamus Hukum: Edisi Baru. Cetakan ke-3. (Jakarta: Rineka Cipta, 2002.) 
Regina Nitami Kasdi \& F.X. Suyud Margono ANALISIS PUTUSAN PENGADILAN NIAGA

\section{Jurnal Hukum Adigamå}

Volume 2 Nomor 2, Desember 2019

E-ISSN : 2655-7347
TERKAIT AKIBAT HUKUM PERMOHONAN PKPU YANG DIAJUKAN OLEH PIHAK YANG TIDAK

(STUDI KASUS PUTUSAN PENGADILAN NIAGA

PADA PENGADILAN NEGERI JAKARTA PUSAT NOMOR 24/PDT.SUS-PKPU/2018/PN.NIAGA.JKT.PST)

\section{B. Peraturan Perundang-undangan}

Indonesia. Kitab Undang-Undang Hukum Perdata

. Undang-Undang Nomor 4 Tahun 1998 tentang Penetapan

Peraturan Pemerintah Pengganti Undang-Undang Nomor 1 Tahun 1998

Tentang Perubahan atas Undang-Undang Tentang Kepailitan Menjadi

Undang-Undang (Lembaran Negara Republik Indonesia Tahun 1998

Nomor 135, Tambahan Lembaran Negara Republik Indonesia Nomor 3778).

Undang-Undang Nomor 37 Tahun 2004 tentang Kepailitan dan

Penundaan Kewajiban Pembayaran Utang (Lembaran Negara

Republik Indonesia Tahun 2004 Nomor 131, Tambahan Lembaran

Negara Republik Indonesia Nomor 4443). 